\title{
PERENCANAAN FILTER PASIF \\ UNTUK MENINGKATKAN KUALITAS DAYA LISTRIK DI KAMPUS DIPLOMA III FAKULTAS TEKNIK UNDIP
}

\author{
Arkhan Subari, Saiful Manan \\ Program Studi Diploma III Teknik Elektro \\ Fakultas Teknik Universitas Diponegoro
}

\begin{abstract}
Arkhan Subari, Saiful Manan, in this paper explain that most electronic equipment is non-linear load. Likewise with the equipment in campus buildings Diploma III Faculty of Engineering. Non-linear load is a load that has a voltage waveform supplied from non sinusiodal although sinusoidal voltage. Non-sinusoidal wave causes the shape of the voltage becomes distorted or defects that result in decreased quality of power. The defect wave called harmonics. To dampen harmonics on non-linear load can be used filter. With the addition of a filter on the power system, then the waves of unwanted harmonics can be suppressed as small as possible. In addition, harmonic filter at the fundamental frequency can compensate for reactive power and is used to improve the power factor of the system. From the measurement results in the Diploma Program Campus FT Undip found that the influence of harmonic waves big enough. THDv reached $32.13 \%$ while the THDi amounted to $7.85 \%$. It affects so cos phi cos phi measured just 0.72. After the installation of a passive filter, the value THDv and THDi be good lebik ie $1.61 \%$ and $0.39 \%$ to reach 0.94 cos phi measured.
\end{abstract}

Key word: non-linear loads, non-sinusoidal waveform, harmonics, power factor, filter LC

\section{PENDAHULUAN}

\section{Latar Belakang}

Energi listrik merupakan komponen penting dalam kehidupan. Salah satu sektor pemakai energi listrik terbesar adalah bangunan perkantoran/ komersial dan sektor industri. Peralatan elektronik seperti komputer, printer dan lampu fluorescent dengan ballast elektronik/Lampu Hemat Energi (LHE) pada umumnya merupakan beban non linier. Demikian halnya di gedung kampus Diploma III Fakultas Teknik Undip.

Beban non linier adalah beban yang memiliki bentuk gelombang tegangan non sinusiodal walaupun disuplai dari tegangan yang sinusoidal. Gelombang yang tidak sinusoidal menyebabkan bentuk tegangan menjadi terdistrosi atau cacat yang berakibat menurunnya kualitas daya. Gelombang cacat tersebut dinamakan harmonisa.

Efek utama dari tegangan dan arus harmonisa dalam sistem tenaga listrik adalah :

- penambahan tingkat harmonisa akibat dari resonansi hubungan seri dan pararel,

- Penurunan efisiensi pada daya generator, transmisi dan pemakaiannya,

- interferensi dengan rangkaian-rangkaian telepon (telekomunikasi) dan pemancar karena arus harmonisa urutan nol,

- kesalahan-kesalahan pada meter-meter piringan putar pengukur energi.

Harmonisa perlu mendapat perhatian karena tanpa disadari dapat menimbulkan kerugian yang relatif besar terutama pada pemakai energi yang besar seperti gedung perkantoran dan sektor industri. Untuk meredam harmonisa pada beban non linier dapat digunakan filter. Filter adalah suatu alat yang memiliki fungsi untuk melewatkan frekuensi tertentu. Dengan penambahan filter pada suatu sistem tenaga listrik, maka gelombang-gelombang harmonisa yang tidak diinginkan dapat ditekan sekecil mungkin. Selain itu, filter harmonisa pada frekuensi fundamental dapat mengkompensasi daya reaktif dan dipergunakan untuk memperbaiki faktor daya sistem.

\section{Perumusan Masalah}

Untuk mengurangi gelombang harminisa dan meningkatkan faktor daya, dirumuskan beberapa permasalahan yaitu :

- Bagaimana cara menghitung parameter beban, khususnya beban non linier di Gedung Kampus Diploma III Fakultas Teknik Undip ?

- Bagaimana cara menghitung filter pasif LC untuk meredam harmonisa di Gedung Kampus Diploma III Fakultas Teknik Undip ?

- Bagaimana perubahan harmonisa terhadap pemasangan filter LC Gedung Kampus Diploma III Fakultas Teknik Undip ?

\section{Tujuan Penelitian}

adalah:

Tujuan yang ingin dicapai pada penelitian ini

- Mengetahui nilai cara menghitung parameter beban, khususnya beban non linier di Gedung Kampus Diploma III Fakultas Teknik Undip ;

- Mengetahui cara menghitung filter pasif LC di Gedung Kampus Diploma III Fakultas Teknik Undip ;

- Mengetahui perubahan harmonisa terhadap pemasangan filter LC Gedung Kampus Diploma III Fakultas Teknik Undip ; 


\section{TINJAUAN PUSTAKA}

Sumber utama harmonik dalam sistem tenaga listrik adalah beban non-linear. Beban nonlinear diklasifikasikan atas tiga tipe, yaitu: (i) peralatan elektronika daya, (ii) peralatan yang menimbulkan busur api, dan (iii) peralatan dengan saturasi inti ferromagnetik (Standart IEEE 5191992). Beban nonlinear adalah beban yang menarik gelombang arus tidak sinusoidal pada saat dicatu oleh sumber tegangan sinusoidal. Apabila terdapat arus harmonik yang terdistorsi akibat adanya beban non-linear maka jatuh tegangan disaluran juga terdistorsi sehingga terjadi perambatan harmonik dalam sistem tenaga listrik yang dapat menganggu unjuk kerja sistem. Bentuk tegangan yang terdistorsi ini mengakibatkan kualitas daya yang disalurkan menjadi berkurang. Hal ini sangat menganggu pada peralatan listrik yang didesain pada gelombang tegangan sinusoidal, akibatnya banyak kerugian yang akan diderita. Peralatan listrik menjadi lebih cepat panas, makin besarnya rugi-rugi daya pada mesin listrik, kegagalan fungsi pada sistem elektronik, sistem komputer, dan sistem kendali. Motor listrik akan mengalami kegagalan pengasutan serta rele proteksi dapat beroperasi salah (Dugan dkk, 1996; IEEE 519-1992)

\section{Defenisi Dasar Harmonik}

Dalam sistem tenaga, harmonik didefenisikan sebagai satu komponen sinusoidal dari satu perioda gelombang yang mempunyai satu frekuensi yang merupakan kelipatan integer dari gelombang fundamental. Jika frekuensi fundamental suatu sistem tenaga adalah $f_{o}$, maka frekuensi harmonik orde $k e-h$ adalah $h f o$.

Sumber tegangan ideal adalah sumber tegangan yang mengeluarkan gelombang sinusoidal tanpa harmonik. Menurut Standart IEEE 519-1992 batas distorsi tegangan yang dinyatakan dalam THD (Total Harmonic Distortion), untuk tegangan sampai $69 \mathrm{KV}$ dibawah 5\% (Emanuel AE, JA Orr. D Cyganski, 1993). Tabel 1 memperlihatkan batas distorsi tegangan harmonik untuk level tegangan yang berbeda. Sedangkan batas distorsi arus untuk sistem tegangan distribusi dari 120 Volt sampai 69.000 Volt diperlihatkan pada tabel 2.

Tabel 1. Batas Distorsi Tegangan

\begin{tabular}{lll}
\hline Tegangan PCC & $\begin{array}{l}\text { Besar } \\
\text { Harmonik } \\
\text { Individual (\%) }\end{array}$ & $\begin{array}{l}\text { THDv } \\
(\%)\end{array}$ \\
\hline $\mathrm{V}<69 \mathrm{kV}$ & 3,0 & 5,0 \\
$69 \mathrm{kV}<\mathrm{V}<161 \mathrm{kV}$ & 1,5 & 2,5 \\
$\mathrm{~V}>161 \mathrm{kV}$ & 1,0 & 1,5 \\
\hline
\end{tabular}

Tabel 2. Batas Distorsi Arus

\begin{tabular}{lllllll}
\hline ISC/IL & $<\mathbf{1 1}$ & $\begin{array}{l}\mathbf{1 1} \\
\mathbf{h}<\mathbf{1 7}\end{array}$ & $\begin{array}{l}\mathbf{1 7 < h} \\
<\mathbf{2 3}\end{array}$ & $\begin{array}{l}\mathbf{2 3 < h} \\
\mathbf{3 5 5}\end{array}$ & $\begin{array}{l}\text { 35> } \\
\mathbf{h}\end{array}$ & TDD \\
& & & & & & \\
\hline$<20$ & 4,0 & 2,0 & 1,5 & 0,6 & 0,3 & 5,0 \\
$20-50$ & 7,0 & 3,5 & 2.5 & 1,0 & 0,5 & 8,0 \\
$50-100$ & 10,0 & 4.5 & 4,0 & 1,5 & 0,7 & 12,0 \\
$100-1000$ & 12,0 & 5,5 & 5,0 & 2,0 & 1,0 & 15,0 \\
$>1000$ & 15,0 & 7,0 & 6,0 & 2,5 & 1,4 & 20,0 \\
\hline
\end{tabular}

\section{Tegangan Harmonik}

Jika harmonik dalam keadaan mantap (steadystate) dipertimbangkan, maka tegangan dan arus sesaat dapat direpresentasikan oleh deret Fourier sebagai:

$$
v(t)=\sum_{h=1}^{\infty} v_{h}(t)=\sum_{h=1}^{\infty} \sqrt{2} V_{h} \sin \left(h \omega_{0} t+\theta_{h}\right)
$$

Dengan mengaplikasikan hubungan orthogonal, maka nilai rms tegangan dapat dicari dengan menggunakan persamaan berikut :

$$
V_{r m s}=\sqrt{\frac{1}{T}} \int_{0}^{T} v^{2}(t) d t=\sqrt{\sum_{n=1}^{\infty} v_{n}}
$$

dimana $n$ merupakan orde harmonik $(n=1,2)$

Bila bagian searah tidak diabaikan, maka persamaan yang berlaku adalah:

$$
\left.\left.V(t)=v_{0}+\sum_{h=1}^{\infty}\left(v_{n} \sin \right) n \omega t+\phi_{n}\right)\right)
$$

Nilai rms (root mean square) dari gelombang tegangan pada persamaan (2) adalah:

$$
V_{r m s}=\left(\frac{1}{2} \int_{0}^{T}\left(v_{0}+\sum_{n=1}^{\infty}\left(v_{n} \sin \left(n \omega t+\Phi_{n}\right)\right)\right)^{2} d t\right)^{1 / 2}
$$

\section{Arus Harmonik}

Gelombang arus pada saat ada harmonik dapat ditulis dalam bentuk persamaan berikut:

$$
\left.\left.i(t)=I_{0}+\sum_{h=1}^{\infty}\left(I_{n} \sin \right) n \omega t+\phi_{n}\right)\right)
$$

dengan: $\mathrm{n}=1,2,3$

In $=$ koefsien komponen harmonik ke-n

$\omega=2$ nf: kecepatan sudut

$\mathrm{f}=$ frekuensi

$\Phi_{\mathrm{n}}=$ sudut fase komponen harmonik ke-n

Komponen harmonik disebut harmonik ganjil apabila $n$ merupakan bilangan ganjil, dan disebut genap bila $n$ merupakan bilangan genap. Nilai rms dari gelombang arus pada persamaan (5) adalah:

$I_{r m s}=\left(\frac{1}{2} \int_{0}^{T}\left(v_{0}+\sum_{n=1}^{\infty}\left(v_{n} \sin \left(n \omega t+\Phi_{n}\right)\right)\right)^{2} d t\right)^{1 / 2}$

Gelombang arus yang mempunyai bentuk simetris setengah gelombang hanya mempunyai 
komponen harmonik ganjil. Gelombang arus yang mengandung komponen harmonik disebut arus yang terdistorsi. Sumbangan masing-masing komponen harmonik terhadap distorsi arus dinyatakan oleh Individual Harmonic Distortion (IHD), sedangkan sumbangan semua komponen harmonik terhadap distorsi arus dinyatakan dengan Total Harmonic Distortion (THD). Semakin besar nilai THD maka arus semakin terdistorsi. Nilai THD untuk gelombang sinusoidal adalah nol. IHD dan THD untuk gelombang arus didefenisikan sebagai berikut:

$$
\begin{aligned}
\text { IHD }= & \frac{I_{n}}{I_{1}} \times 100 \% \\
T H D= & \frac{\sqrt{\sum_{h=2}^{\infty} I_{h}^{2}}}{I_{1}} \times 100 \% \\
\text { dengan : } \quad \mathrm{n}= & 1,2,3, \\
\mathrm{I}_{1}= & \text { Nilai efektif gelombang dasar } \\
\mathrm{In}= & \text { Nilai efektif gelombang } \\
& \text { harmonik ke-n }
\end{aligned}
$$

\section{Total Harmonik Distortion (THD)}

THD (Total Harmonik Distortion) didefenisikan sebagai perbandingan nilai rms komponen harmonik terhadap komponen dasar dan biasanya dalam persen (\%). Indek ini digunakan untuk mengukur penyimpangan (deviation) dari bentuk gelombang satu periode yang mengandung harmonik pada satu gelombang sinus sempurna. Untuk satu gelombang sinus sempurna pada frekuensi dasar, THD adalah nol. Demikian pula untuk pengukuran distorsi harmonik individual untuk tegangan dan arus pada orde ke-h didefenisikan sebagai $V_{h} / V_{l}$ dan $\mathrm{I}_{\mathrm{h}} / \mathrm{I}_{1}$. (Andi Syofian, Anju Martulesi, Nining Nadya, 2008)

$$
\begin{gathered}
\text { THD tegangan } T H D_{V}=\frac{\sqrt{\sum_{h=2}^{\infty} V_{h}^{2}}}{V_{1}} \times 100 \\
\text { THD arus } T H D_{1}=\frac{\sqrt{\sum_{h=2}^{\infty} I_{h}^{2}}}{I_{1}} \times 100
\end{gathered}
$$

\section{Total Demand Distortion (TDD)}

TDD (Total Demand Distortion) merupakan distorsi harmonik arus total yang dapat dinyatakan sebagai berikut:

$$
T D D=\frac{\sqrt{\sum_{h=2}^{\infty} I_{h}^{2}}}{I_{L}}
$$

dimana $I_{L}$ adalah arus beban maksimum yang dibutuhkan (the maximum demand load current), dalam 15 dan 30 menit pada frekuensi fundamental pada titik sambungan bersama (the point of common coupling, $P C C)$.

\section{Tapis Pasif (Passive filter)}

Filter pasif terdiri dari elemen induktans, kapasitans dan resistans (Dugan, dkk, 1996). Elemen-elemennya relatif murah dibandingkan dengan elemen yang lain dan digunakan untuk mengurangi distorsi harmonik, tapi mempunyai kerugian yaitu adanya interaksi potensial yang berlawanan dengan sistem tenaga. Elemen-elemen ini dipakai secara paralel untuk menghilangkan arus harmonik pada saluran, atau untuk menahan/memblok aliran aliran anus harmonik diantara bagian-bagian dari sistem dengan menala elemen-elemennya untuk beresonansi pada frekuensi tertentu. (Dugan, dkk,1996).

Rangkaian filter secara umum digunakan untuk melewatkan sinyal dengan range frekuensi spesifik dan menolak atau mengurangi sinyal yang sinyal spektrum frekuensinya diluar fekuensi yang dilewatkan (Sabar Nababan, 2001). Filter yang biasanya digunakan adalah tapis pelewat rendah (low pass filter), tapis pelewat tinggi (high pass filter), tapis yang melewatkan frekuensi pada range tertentu (band pass filter) dan tapis yang memblok pada frekuensi tertentu (band rejection filter).

Pengurangan harmonik dapat dilakukan dengan beberapa cara diantaranya adalah dengan menginjeksikan harmonik (harmonik injection), mengijneksikan riak $D C$ (DC ripple injection), mengkompensasi fluks magnetik (magnetic flue compensation), dan pemasangan filter. Untuk pemasangan filter ada bermacam-macam cara diantaranya adalah tapis penala (tuning filter) dan filter peredam (damping filter).

Tapis pasif pelewat rendah (low pass passive filter)

Tapis pasif pelewat rendah (low pass passive filter) merupakan tapis yang terdiri dari komponen resistan, induktans dan kapasitans yang dapat melewatkan frekuensi dibawah frekuensi cut-off dan menahan frekuensi diatas frekuensi cutoff. Gambar.1 memperlihatkan tipe tapis pelewat rendah LC dan RC. Pada tapis pasif tipe RL, nilai sinyal dapat ditentukan dengan menggunakan persamaan (11). Sedangkan pada tapis RC nilai sinyal keluaran dapat ditentukan dengan menggunakan persamaan (12).

$$
\begin{aligned}
& V_{0}=\left(\frac{1 / j \varpi C}{R+j \varpi L+1 / J \omega C}\right) V_{s} \\
& V_{0}=\left(\frac{1}{1 / J \omega R C}\right)
\end{aligned}
$$

dimana $\mathrm{V}_{0}$ adalah sinyal keluaran tapis, dan $\mathrm{Vs}$ merupakan sinyal masukan. Sedangkan tahanan $\mathrm{R}$ 
pada tapis pasif pelewat rendah tipe LC merupakan tahanan dalam induktor.

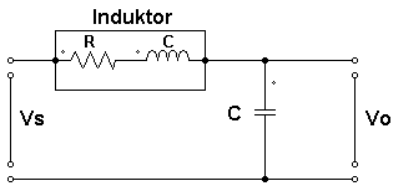

(a) Tipe LC

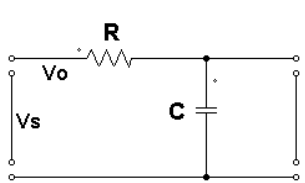

(b) Tipe RC,
Gambar 2.1. Rangkaian filter pasif pelewat rendah

Pada penelitian ini filter pasif yang digunakan untuk meredam harmonik merupakan filter pasif penalaan tunggal dengan menggunakan komponen induktans dan kapasitans. Tipe filter pasif yang digunakan adalah tipe LC, dimana nilai impedans rangkaian filternya dapat ditentukan dengan persamaan (13) pada sisi sumber atau input, dan pada sisi out put nilai impedans dapat ditentukan dengan menggunakan persamaan (14).

$$
\begin{aligned}
& Z=R+j \omega L+\frac{1}{j \omega C} \\
& Z=\frac{1}{j \omega C}
\end{aligned}
$$

bagian imajiner impedans pada persamaan (14) akan mempunyai nilai nol jika :

$$
\omega L=\frac{1}{\omega C}
$$

sehingga nilai $\omega$ adalah :

$$
\omega_{0}=\frac{1}{\sqrt{L C}}
$$

dimana $\omega_{0}=2 \pi \mathrm{f}$ dengan $\mathrm{f}_{0}$ merupakan frekuensi resonansi atau cut-off dimana nilai impedansi bagian imajiner pada frekuensi ini adalah nol (Sabar Nababan, 2001).

Rangkaian tapis pasif pelewat rendah yang terdiri dari komponen induktan $\mathrm{L}$, tahanan dalam $\mathrm{R}$ dan kapasitor $\mathrm{C}$, maka kualitas atau ketajaman penalaan tapis sangat dipengaruhi oleh faktor kualitas (quality factor) Q yang dapat dinyatakan dengan menggunakan persamaan (17). Faktor kualitas Q, yang sangat penting pada rangkaian resonanasi. Nilai faktor kualitas Q akan mempengaruhi nilai impedansi sebagai fungsi frekuensi.

$$
Q=\frac{\omega_{0} L}{R}=\frac{1}{\omega_{0} C R}=\frac{1}{R} \sqrt{\frac{L}{C}}
$$

\section{Penentuan parameter $L$ dan $C$ pada filter}

Perancangan filter pasif pelewat rendah pada penelitian ini menggunakan koponen induktor dan kapasitor. Nilai parameter induktor dan kapasitor dapat ditentukan dengan terlebih dahulu menentukan nilai frekuensi cut-off yaitu untuk menentukan pada frekuensi berapa sinyal dapat dilewatkan. Pada penelitian ini nilai induktans dapat ditentukan dengan menggunakan persamaan (17) dengan menetukan nilai kapasitornya terlebih dahulu.

$$
\begin{aligned}
& L=\frac{1}{\omega_{0}^{2} C} \text { Henry } \\
& C=\frac{1}{\omega_{0}^{2} L} \text { farad }
\end{aligned}
$$

\section{PEMBAHASAN \\ Harmonik Sumber Tegangan Sebelum dipasang} Filter

Sumber tegangan yang digunakan pada penelitian ini adalah tegangan dari jaringan listrik PLN tiga fasa pada kampus DIII Fakultas Teknik Undip. Hasil pengukuran harmonik tegangan fasa ke netral sampai dengan harmonik ke-20 dengan menggunakan HIOKI3286-20 ditampilkan pada Tabel 3. Gambar 1 dan 2 memperlihatkan spektrum harmonik tegangan dan harmonik arus pada sumber tegangan jala-jala sampai pada harmonik ke-20.

Berdasarkan spektrum harmonik dan bentuk gelombang pada gambar 1 dan 2 dapat dianalisa bahwa komponen harmonik tegangan dan harmonik arus tertinggi terjadi pada harmonik ke-3, yaitu pada frekuensi $150 \mathrm{~Hz}$. Nilai harmonik tegangan dan harmonik arus pada orde ke-3 masing-masing fasa adalah : fasa $\mathrm{R}=4,84 \%$ dan $15,69 \%$; fasa $\mathrm{S}=$ $5,97 \%$ dan $28,43 \%$; fasa $\mathrm{T}=4,94 \%$ dan $15,83 \%$ sehingga pada perancangan filter pasif frekuensi cut-off diambil pada frekuensi 150 $\mathrm{Hz}$. Pemasangan filter pasif pada frekuensi cut-off $150 \mathrm{~Hz}$ diharapkan dapat meredam harmonik tegangan dan arus pada orde ke-3, dan seterusnya.

\section{Perancangan Filter Pasif Pelewat Rendah}

Berdasar pada hasil pengamatan di atas, maka didesain filter pasif yang terdiri dari komponen induktor dan kapaistor. Filter yang digunakan merupakan filter pasif pelewatrendah, yaitu filter yang hanya melewatkan frekuensi dibawah frekuensi cut-off. Sedangkan frekuensi di atas frekuensi cut-off akan di potong atau akan mengalami penurunan amplitudo.

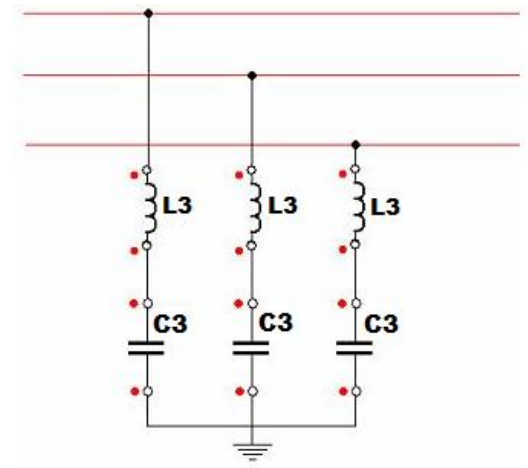

Gambar 3. Rangkaian Filter Pasif yang digunakan pada Penelitian 
Tabel 3. Hasil pengukuran tegangan dan arus harmonik sebelum dipasang Filter

\begin{tabular}{|c|c|c|c|c|c|c|}
\hline \multirow{2}{*}{$\begin{array}{c}\text { Orde } \\
\text { Harmonik }\end{array}$} & \multicolumn{2}{|c|}{$\mathbf{R}$} & \multicolumn{2}{|c|}{$\mathbf{S}$} & \multicolumn{2}{|c|}{$\mathbf{T}$} \\
\hline & I (\%) & $\mathrm{V}(\%)$ & I (\%) & $\mathrm{V}(\%)$ & I (\%) & $\mathrm{V}(\%)$ \\
\hline 1 & 100.00 & 100.00 & 100.00 & 100.00 & 100.00 & 100,00 \\
\hline 2 & 11,46 & 1,94 & 5,88 & 1,68 & 15,83 & 0,34 \\
\hline 3 & 15,69 & 4,84 & 28,43 & 5,97 & 15,83 & 4,94 \\
\hline 4 & 0,60 & 1,16 & 0,98 & 0,56 & 4,17 & 0,51 \\
\hline 5 & 7,24 & 2,52 & 9,80 & 1,49 & 9,17 & 2,05 \\
\hline 6 & 0,60 & 0,97 & 1,96 & 0,37 & 2,50 & 0,34 \\
\hline 7 & 2,41 & 2,91 & 3,92 & 1,86 & 2,50 & 2,39 \\
\hline 8 & 0,00 & 0,58 & 0,98 & 0,00 & 0,00 & 0,68 \\
\hline 9 & 1,81 & 1,36 & 6,86 & 3,17 & 2,50 & 2,39 \\
\hline 10 & 1,21 & 0,58 & 0,00 & 0,19 & 0,00 & 0,17 \\
\hline 11 & 1,21 & 0,78 & 3,92 & 1,86 & 2,50 & 1,02 \\
\hline 12 & 0,00 & 0,39 & 0,00 & 0,37 & 0,00 & 0,00 \\
\hline 13 & 1,21 & 0,19 & 1,96 & 0,56 & 0,83 & 0,68 \\
\hline 14 & 0,00 & 0,19 & 0,00 & 0,37 & 0,00 & 0,17 \\
\hline 15 & 1,21 & 0,39 & 1,96 & 1,31 & 0,83 & 0,85 \\
\hline 16 & 0,00 & 0,39 & 0,00 & 0,19 & 0.00 & 0,00 \\
\hline 17 & 0,60 & 0,39 & 0,98 & 0,93 & 0,00 & 0,51 \\
\hline 18 & 0,00 & 0,00 & 0,00 & 0,00 & 0,00 & 0,17 \\
\hline 19 & 0,00 & 0,19 & 0,98 & 0,56 & 0,83 & 0,51 \\
\hline 20 & 0,00 & 0,00 & 0,00 & 0,00 & 0,00 & 0,17 \\
\hline THD & $21,12 \%$ & $6,94 \%$ & $32,13 \%$ & $7,85 \%$ & $25,10 \%$ & $6,62 \%$ \\
\hline Cos phi & \multicolumn{2}{|c|}{0,76} & \multicolumn{2}{|c|}{$\mathbf{0 , 7 2}$} & \multicolumn{2}{|c|}{$\mathbf{0 , 7 3}$} \\
\hline
\end{tabular}

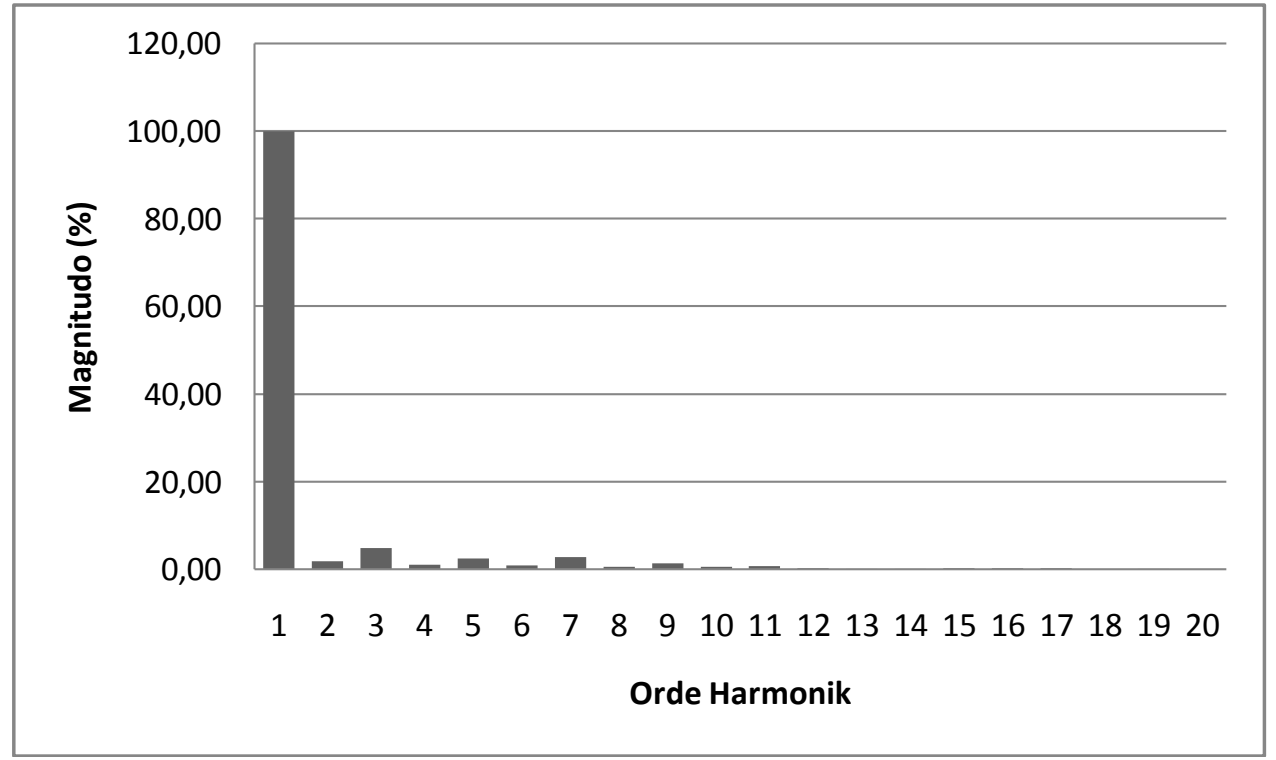

Gambar 1. Spektrum Harmonik Tegangan Fasa R sebelum di Filter 


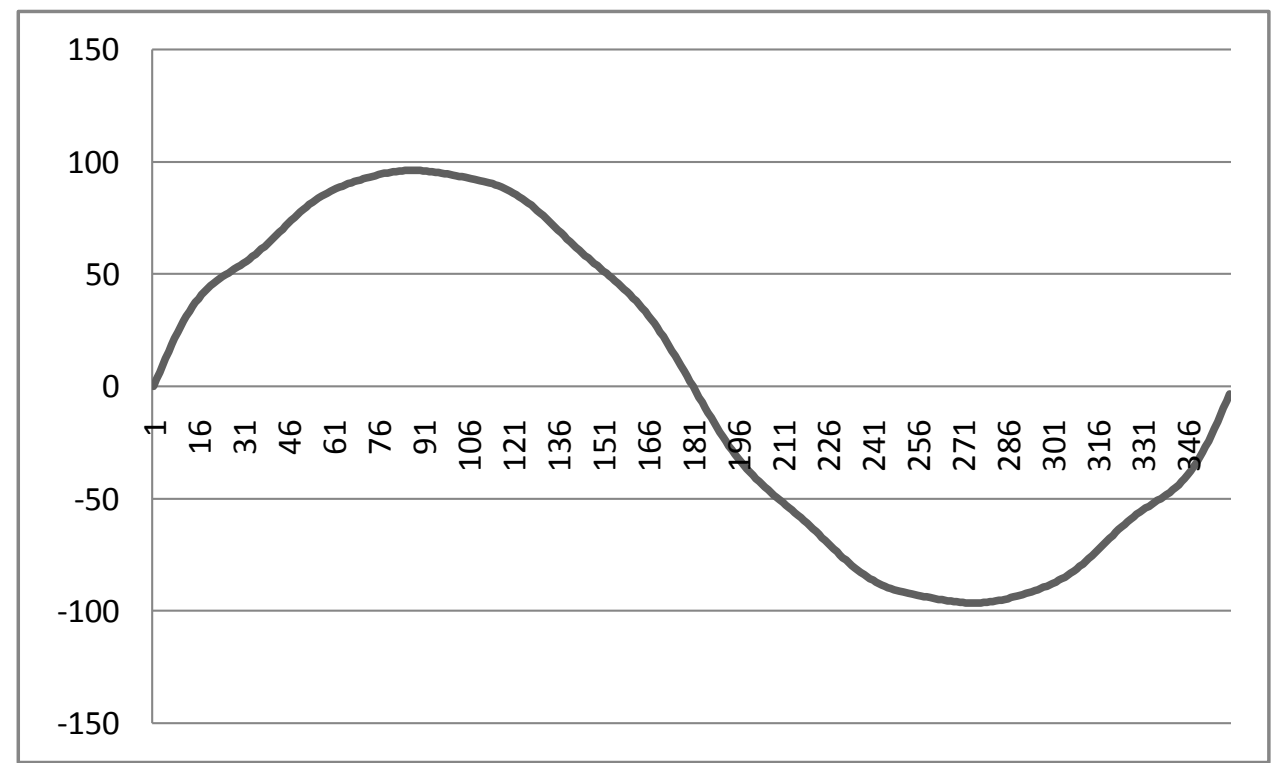

Gambar 2. Gelombang Tegangan Fasa R Sebelum di filter

Rangkaian filter pasif yang digunakan dalam penelitian diperlihatkan pada Gambar 3. Nilai komponen induktor dan kapasitor dihitung sebagai berikut :

$$
\begin{aligned}
& V L L=357,5 \\
& V p h=\frac{V L L}{\sqrt{3}}=\frac{357,5}{\sqrt{3}}=206,4 \\
& I R=66,3 \mathrm{~A} \\
& P \quad=10.400,08 \mathrm{~W} \\
& P F 1=0,76 \rightarrow \theta 1=40,535^{\circ} \\
& P F 2=0,795 \rightarrow \theta 1=18,195^{\circ} \\
& Q c=P\left(\operatorname{tg} \theta_{1}-\operatorname{tg} \theta_{2}\right) \\
& =10.400,08(0,855-0,328) \\
& =5480,28 \mathrm{VAR} \\
& C_{\text {star }}=\frac{Q c}{V L L \times W}=\frac{5480,28}{357,5 \times 6,28 \times 50} \\
& =0,048820=48.820 \mu F \\
& \text { Ln }=\frac{1}{4 \pi^{2} n^{2} \quad C}=136,559 \mu F \\
& L_{3}=\frac{1}{4 \times 3,14^{2} \times 150^{2} \times 136,559 \mu F} \\
& =8,25 \mathrm{mH}
\end{aligned}
$$

$$
\begin{aligned}
& h=\frac{12}{0,6561}=18,28 \\
& A c=b \times h=12 \times 18,28=219,36 \\
& \quad n_{n}=\frac{8,25 \mathrm{mH} \times 100 \times 10^{4}}{2 \times 219,36}=18,80
\end{aligned}
$$

\section{Harmonik Beban Listrik Pada Kampus DIII FT Undip Setelah Dipasang Filter}

Hasil pengukuran harmonik tegangan fasa ke netral sampai dengan harmonik ke-20 dengan menggunakan HIOKI 3286-20 setelah dipasang filter ditampilkan pada Tabel 4.

Pemasangan Filter bertujuan untuk mengurangi atau meredam komponen harmonik pada orde ke-3 ke atas serta memperbaiki faktor daya. Data pengukuran setelah dipasang filter pada beban listrik kampus DIII FT Undip secara keseluruhan memperlihatkan bahwa terjadi penurunan arus dan tegangan harmonik serta meningkatnya faktor daya. Gambar 3 dan 4 memperlihatkan spektrum harmonik tegangan dan harmonik arus pada beban listrik kampus DIII FT Undip untuk masing-masing fasa. 
Tabel 4. Hasil pengukuran tegangan dan arus harmonik setelah dipasang Filter

\begin{tabular}{|c|c|c|c|c|c|c|}
\hline \multirow{2}{*}{$\begin{array}{c}\text { Orde } \\
\text { Harmonik }\end{array}$} & \multicolumn{2}{|c|}{$\mathbf{R}$} & \multicolumn{2}{|c|}{$\mathbf{S}$} & \multicolumn{2}{|c|}{$\mathbf{T}$} \\
\hline & I (\%) & $\mathrm{V}(\%)$ & I (\%) & $\mathrm{V}(\%)$ & I (\%) & $\mathrm{V}(\%)$ \\
\hline 1 & 100,00 & 100,00 & 100,00 & 100,00 & 100,00 & 100,00 \\
\hline 2 & 0,57 & 0,10 & 0,29 & 0,08 & 0,79 & 0,02 \\
\hline 3 & 0,78 & 0,24 & 1,42 & 0,30 & 0,79 & 0,25 \\
\hline 4 & 0,03 & 0,06 & 0,05 & 0,03 & 0,21 & 0,03 \\
\hline 5 & 0,36 & 0,13 & 0,49 & 0,07 & 0,46 & 0,10 \\
\hline 6 & 0,03 & 0,05 & 0,10 & 0,02 & 0,13 & 0,02 \\
\hline 7 & 0,12 & 0,15 & 0,20 & 0,09 & 0,13 & 0,12 \\
\hline 8 & 0,00 & 0,03 & 0,05 & 0,00 & 0,00 & 0,03 \\
\hline 9 & 0,09 & 0,07 & 0,34 & 0,16 & 0,13 & 0,12 \\
\hline 10 & 0,06 & 0,03 & 0,00 & 0,01 & 0,00 & 0,01 \\
\hline 11 & 0,06 & 0,04 & 0,20 & 0,09 & 0,13 & 0,05 \\
\hline 12 & 0,00 & 0,02 & 0,00 & 0,02 & 0,00 & 0,00 \\
\hline 13 & 0,06 & 0,01 & 0,10 & 0,03 & 0,04 & 0,03 \\
\hline 14 & 0,00 & 0,01 & 0,00 & 0,02 & 0,00 & 0,01 \\
\hline 15 & 0,06 & 0,02 & 0,10 & 0,07 & 0,04 & 0,04 \\
\hline 16 & 0,00 & 0,02 & 0,00 & 0,01 & 0,00 & 0,00 \\
\hline 17 & 0,03 & 0,02 & 0,05 & 0,05 & 0,00 & 0,03 \\
\hline 18 & 0,00 & 0,00 & 0,00 & 0,00 & 0,00 & 0,01 \\
\hline 19 & 0,00 & 0,01 & 0,05 & 0,03 & 0,04 & 0,03 \\
\hline 20 & 0,00 & 0,00 & 0,00 & 0,00 & 0,00 & 0,01 \\
\hline THD & $1,06 \%$ & $0.35 \%$ & $1,61 \%$ & $0,39 \%$ & $1,25 \%$ & $0,33 \%$ \\
\hline Cos phi & \multicolumn{2}{|c|}{0,95} & \multicolumn{2}{|c|}{0,94} & \multicolumn{2}{|c|}{$\mathbf{0 , 9 5}$} \\
\hline
\end{tabular}

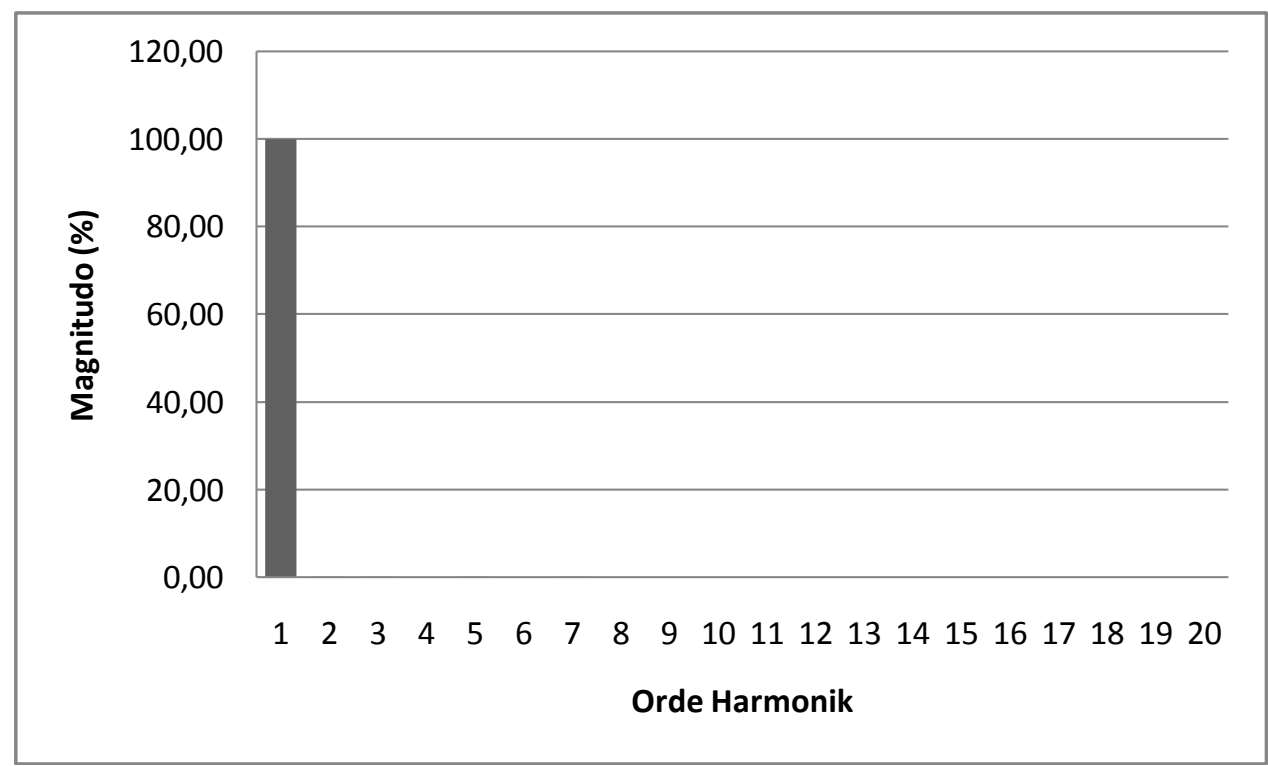

Gambar 3. Spektrum Harmonik Tegangan Fasa R Setelah di Filter 


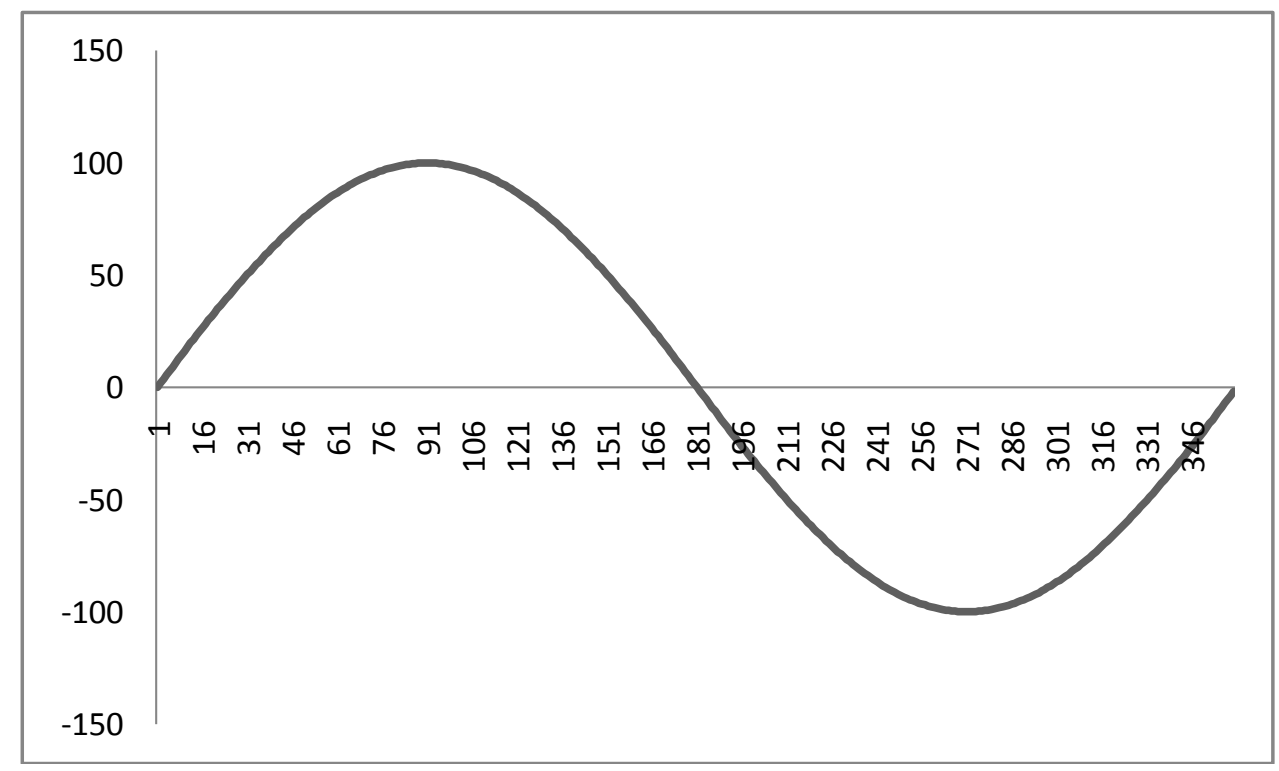

Gambar 4. Gelombang Tegangan Fasa R Setelah di Filter

Dari pengukuran dan pengamatan di atas nilai komponen tegangan dan arus harmonik setelah pemasangan filter jauh berkurang sehingga bentuk gelombang tegangan dan arus mendekati bentuk sinusoidal.

Nilai THD tegangan dan THD arus setelah dipasang filter masing-masing fasa adalah : fasa $\mathrm{R}=$ $0,35 \%$ dan $1,06 \%$; fasa $S=0,39 \%$ dan $1,61 \%$; fasa $\mathrm{T}=0,33 \%$ dan $1,25 \%$. Selain perbaikan THD, pemasangan filter juga memperbaiki faktor daya untuk masing-masing fasa yaitu : fasa $\mathrm{R}=0,95$; fasa $\mathrm{S}=0,94$; fasa $\mathrm{T}=0,95$.

Dengan demikian maka terlihat bahwa setelah dilakukan pemasangan filter dengan frekuensi cut-off $150 \mathrm{~Hz}$ nilai komponen harmonik pada kampus DIII FT Undip me menuhi standar IEEE 519-1992.

\section{KESIMPULAN DAN SARAN}

Berdasar pada data penelitian dan pembahasan, maka dapat diambil beberapa kesimpulan :

- Beban listrik pada kampus DII FT Undip mengakibatkan distorsi harmonik arus dan tegangan serta penurunan faktor daya menjadi 0,72 Sehingga tidak memenuhi standar mutu berdasarkan standar IEEE 519-1992.

- Untuk memperbaiki kualitas daya listrik di kampus DIII FT diperlukan pemasangan Filter dengan fungsi untuk meredam distorsi harmonik dan perbaikan faktor daya.

- Filter yang dipasang adalah Filter pasif LC dengan frekuensi cutt off $150 \mathrm{~Hz}$.
- Dengan pemasangan filter pasif LC terjadi perbaikan mutu kualitas daya listrik pada kampus DIII FT Undip yaitu dengan menurunnya nilai THD dan naiknya power faktor menjadi 0,94 .

\section{DAFTAR PUSTAKA}

1. Andi Syofian, Anju Martulesi, Nining Nadya, 2008, Perencanaan Dan Analisis Penentuan Letak Filter Harmonik Pada Sistem Tenaga Listrik, Prosiding Seminar Nasional Teknoin 2008 Bidang Teknik Elektro

2. Dugan, R.C, McGranaghan M.F, Beaty H.W., 1996, Electrical Power System Quality, McGraw-Hill Book Company, New York.

3. Emanuel AE, JA Orr. D Cyganski, 1993, A survey of Harmonic Voltages and Currents at the Customers's bus, IEEE. Trans.on Power Delivery. New York.

4. Sabar Nababan, 2001, Tapis Parallel Pasif Untuk Mengurangi Distorsi Harmonik Beban Taklinear, Thesis JTE FT. UGM, Yogyakarta. 